\title{
BENTUK-BENTUK JAMINAN SOSIAL DAN \\ MANFAATNYA BAGI TENAGA KERJA \\ DALAM HUKUM KETENAGAKERJAAN INDONESIA
}

\author{
Junaidi Abdullah \\ Institut Agama Islam Negeri Kudus \\ Joened1@yahoo.com/abdillahrafandra@gmail.com
}

\begin{abstract}
Labor in carrying out his work certainly has arisk of risk that is likely to occur to the worker himself, both the risk o illness resulting from his job, the risk of accident, the risk of disability, the risk of losing his jib and even the risk of death. Social security for the labor is a protection and will provide benetits for thr laboritself and for the family from unexpected thing due to the risk possed in carrying out their work.

Forms of social security for workers include : work accident insurance, old age insurance, pension insurance and life insurance.

Thr benefit of job accident is to get health service, according to mrdical needs and get compassion in the form of money. The benefits of old age collateral get cash and housing finance. While pension insurance benefits will get old age pension, disability pension, widow or widower pension, child pension and parental retirement. Then death benefit benefits get education benefit and scholarship.

Key word: Social security, benefit
\end{abstract}

\section{A. Pendahuluan}

Indonesia merupakan negara yang berlandaskan hukum, tentu dalam menalankan pemerintahan, menjalin hubungan negara dengan masyarakat, dan masyarakat dengan masyarakat .akan berdasakan aturan-aturan hukum yang dibuat oleh oleh negara.

Salah satu bentuk pengaturan negara terhadap hubungan pemerintah dengan masyarakat, hubungan masyarakat dengan masyarakat adalah dalam hal aturan ketenagakerjaan. Karena dalam hal ketenagakerjaan akan melibatkan hubungan tripartit, yakni pemerintah, pengusaha dan tenaga kerja atau karyawan. Contoh 
riilnya adalah masalah penetapan upah dan jaminan social bagi tenaga kerja.

Jaminan social bagi tenaga kerja merupakan sebuah perlindungan dan akan memberikan manfaat bagi tenaga keja itu sendiri maupun bagi keluarganya dari hal-hal yan terduga akibat resiko yang ditimbulkan dalam menjalankan pekerjaannya.

Tenaga kerja dalam melaksanakan pekerjaannya tentu punya resiko-resiko yang kemungkinan akan terjadi pada diri pekerja, baik resiko penyakit yang di timbulkan dari pekerjaannya, resiko kecelakaan, resiko cacat, resiko kehilangan pekerjaannya bahkan resiko kematian.

Risiko adalah faktor ketidakpastian dari suatu aktivitas yang kita lakukan baik dalam hubungan kerja maupun di luar hubungan kerja. Pengertian lain dari risiko adalah potensi kehilangan atau kerugian. Risiko dapat dibedakan atas tiga (3) hal: yaitu risiko finansial, risiko operasional dan risiko murni (Bambang Purwoko; 1: 2010).

Risiko terdapat dalam berbagai bidang dan bisa digolongkan dalam dua kelompok utama, yaitu risiko fundamental dan risiko khusus. Risiko fundamental ini sifatnya kolektif dan dirasakan oleh seluruh masyarakat, seperti risiko politis, social, hankam dan internasional. Sedangkan risiko khusus, sifatnya lebih individual karena dirasakan oleh perorangan, seperti risiko terhadap harta benda, terhadap diri sendiri dan terhadap kegagalan usaha (Zainal asikin dkk ; 2002 : 77). Maka untuk mengurangi risiko-risiko tersebut diatas, maka jaminan social bagi tenaga kerja sangatlah penting dan bermanfaat bagi tenaga kerja itu sendiri maupun keluarganya.

Menurut Iman Soepomo Jaminan sosial adalah pembayaran yang diterima pihak buruh dalam hal buruh di luar kesalahannya tidak melakukan pekerjaannya, jadi menjamin kepastian pendapatan (income security) dalam hal buruh kehilangan upahnya karena alasan di luar kehendaknya (Imam Supomo; 1983 ; 136).

Dalam Pasal 1 Undang-Undang Nomor. 40 tahun 2004 tentang Sistem Jaminan Sosial Nasional mendefinisikan jaminan sosial sebagai salah satu bentuk perlindungan untuk menjamin seluruh rakyat agar dapat memenuhi kebutuhan hidupnya yang layak. Adapun Sistem Jaminan Sosial Naasioanal itu sendiri sebagai suatu tata-kelola penyelenggaraan program jaminan sosial oleh beberapa badan penyelenggara jaminan social (Undang- 
Undang Nomor. 40 tahun 2004 tentang Sistem Jaminan Sosial Nasional).

Sedangkan Purwoko menyatakan bahwa jaminan sosial sebagai salah satu faktor ekonomi yang memberikan manfaat tunai kepada peserta sebagai pengganti penghasilan yang hilang, karena peserta mengalami berbagai musibah seperti sakit, kecelakaan, kematian prematur, pemutusan hubungan kerja sebelum usia pensiun dan hari tua. Penyelenggaraan sistem jaminan sosial ini bersifat nasional sesuai Undang Undang Jaminan Sosial dimana pendanaannya berasal dari iuran iuran peserta yang terdiri dari iuran pemberi kerja dan pekerja. Adapun iuran yang belum jatuh tempo berfungsi sebagai tabungan dan atau investasi sedang iuran yang telah jatuh tempo merupakan fungsi konsums. (Bambang Purwoko; 5-6 : 2010).

Jaminan Sosial tenaga Kerja adalah hak karyawan dan kewajiban pengusaha, maka hakikatnya program jamsostek dimaksudkan untuk memberikan kepastian berlangsungnya arus penerimaan penghasilan keluarga sebagai pengganti sebagian atau seluruh penghasilan yang hilang (Lalu Husni; 2003 : 123).

Dari beberapa pengertian diatas, maka dapat di simpulkan bahwa jaminan sosial tenaga kerja merupakan bentuk perlindungan atas resiko-resiko yang mungkin di dapatkan bagi tenaga kerja dalam menjalakan kewajibannya, yakni berupa manfaat-manfaat berupa perawatan, santunan maupun manfaat-manfaat yang lainnya.

Dari segi sejarah pelaksana, pelaksana jaminan sosial bagi tenaga kerja di lakukan oleh PT. Jamsostek, namun dengan berlakunya Undang-Undang Nomor 24 tahun 2011 tentang Badan Penyelenggara Jaminan Sosial, maka pelaksana dari jaminan social tenaga kerja di lakukan oleh PT. BPJS, lebih spesifik lagi adalah PT. BPJS ketenagakerjaan.

\section{B. Program Jaminan Sosial bagi Tenaga Kerja}

Menurut Undang Undang Nomor 24 tahun 2011 pasal 6 ayat 2 bahwa BPJS Ketenagakerjaan berhak menyelenggarakan Jaminan Kecelakaan Kerja (JKK), Jaminan Hari Tua (JHT), Jaminan Pensiun (JP) dan Jaminan Kematian (JKM).

\section{Jaminan Kecelakaan Kerja}

Tenaga kerja dalam menjalankan pekerjaannya tentu tidak akan lepas dari resiko-resiko yang diakibatkan oleh 
pekerjaannya. Misalnya resiko kecelakaan kerja yang bisa menyebabkan cacat bahkan kematian.

Yang dimaksud dengan Jaminan Kecelakaan Kerja yang selanjutnya disingkat JKK adalah manfaat berupa uang tunai dan/atau pelayanan kesehatan yang diberikan pada saat peserta mengalami kecelakaan kerja atau penyakit yang disebabkan oleh lingkungan kerja (Pasal 1 ayat 1 Peraturan Pemerintah Nomor 44 tahun 2015 tentang Penyelenggaraan Program Jaminan Kecelakaan Kerja dan Jaminan Kematian).

Yang masuk kriteria kecelakaan kerja adalah kecelakaan yang terjadi dalam hubungan kerja, termasuk kecelakaan yang terjadi dalam perjalanan dari rumah menuju tempat kerja atau sebaliknya dan penyakit yang disebabkan oleh lingkungan kerja.

Peserta dari program Jaminan Kecelakan Kerja (JKK) bisa dilakukan oleh peserta penerima upah yang bekerja pada pemberi upah selain pemerintah atau Negara, bahkan pekerja asing yang bekerja di Indonesia minimal 6 bulan wajib menjadi peserta dan bisa di ikuti oleh bukan penerima upah.

Peserta penerima upah, terdiri dari :

a. Pekerja pada perusahaan

b. Pekerja pada orang perseorangan

c. orang asing yang bekerja di Indonesia paling singkat 6 (enam) bulan.

Sedangkan peserta bukan penerima upah terdiri dari :

a. Pemberi kerja

b. Pekerja di luar hubungan kerja atau pekerja mandiri

c. Pekerja yang tidak termasuk huruf $\mathrm{b}$ yang bukan menerima upah.(Peraturan Pemerintah Nomor 44 tahun 2015 tentang Penyelenggaraan Program Jaminan Kecelakaan Kerja dan Jaminan Kematian).

Besarnya iuran program Jaminan Kecelakaan Kerja (JKK) bagi peserta penerima upah dikelompokkan dalam 5 (lima) kelompok tingkat risiko lingkungan kerja, yang meliputi :

a. tingkat risiko sangat rendah : $0,24 \%$ (nol koma dua puluh empat persen) dari upah sebulan

b. tingkat risiko rendah : 0,54\% (nol koma lima puluh empat persen) dari upah sebulan

c. tingkat risiko sedang : 0,89\% (nol koma delapan puluh sembilan persen) dari upah sebulan 
d. tingkat risiko tinggi : 1,27\% (satu koma dua puluh tujuh persen) dari upah sebulan (www.hukumonline.com)

e. tingkat risiko sangat tinggi : $1,74 \%$ (satu koma tujuh puluh empat persen) dari Upah sebulan. (Penggolongan ini bisa dilihat dalam lampiran Peraturan Pemerintah Nomor 44 tahun 2015 tentang Penyelenggaraan Program Jaminan Kecelakaan Kerja dan Jaminan Kematian).

Pengelompokan tingkat risiko lingkungan kerja dievaluasi paling lama setiap 2 (dua) tahun dan hasil evaluasi digunakan sebagai bahan perubahan pengelompokan tingkat risiko lingkungan kerja (Pasal 16-19 Peraturan Pemerintah Nomor 44 tahun 2015 tentang Penyelenggaraan Program Jaminan Kecelakaan Kerja dan Jaminan Kematian)..

Sedangkan iuran Jaminan Kecelakaan Kerja (JKK) bagi peserta bukan penerima upah didasarkan pada nilai nominal tertentu dari penghasilan. Besarnya iuran dipilih oleh peserta sesuai penghasilan peserta setiap bulan (Pasal 20 Peraturan Pemerintah Nomor 44 tahun 2015 tentang Penyelenggaraan Program Jaminan Kecelakaan Kerja dan Jaminan Kematian).

\section{Jaminan Hari Tua}

Pekerjaan merupakan salah satu komponen yang sangat penting bagi pekerja. Tidak bisa di bayangkan kalau seorang pekerja tidak mempunyai pekerjaan baik itu karena cacat atau karena faktor usianya yang tidak mungkin di terima oleh sebuah perusahaan. Hal ini akan mempersulit kehidupan bagi dirinya maupun keluarganya. Maka salah satu cara untuk menghadapi resiko ini, pekerja harus mempersiapkan diri dengan mengikuti program Jaminan Hari Tua.

Yang di maksud dengan Jaminan Hari Tua yang selanjutnya disingkat JHT adalah manfaat uang tunai yang dibayarkan sekaligus pada saat peserta memasuki usia pensiun, meninggal dunia, atau mengalami cacat total tetap.( Pasal 1 Peraturan Pemerintah Nomor 46 tahun 2015 tentang Penyelenggaraan Program Jaminan Hari Tua).

Peserta dari Program Jaminan Hari Tua (JHT) bisa dilakukan oleh peserta penerima upah yang bekerja pada pemberi upah selain pemerintah atau Negara, bahkan pekerja 
asing yang bekerja di Indonesia minimal 6 bulan wajib menjadi peserta dan bisa di ikuti oleh bukan penerima upah.

Peserta penerima upah, meliputi:

a. Pekerja pada perusahaan

b. Pekerja pada orang perseorangan

c. orang asing yang bekerja di Indonesia paling singkat 6 (enam) bulan.

Sedangkan peserta bukan penerima upah meliputi:

a. Pemberi kerja

b. Pekerja di luar hubungan kerja atau pekerja mandiri

c. Pekerja yang tidak termasuk huruf $\mathrm{b}$ yang bukan menerima upah.(Peraturan Pemerintah Nomor 46 tahun 2015 tentang Penyelenggaraan Program Jaminan Hari Tua).

Besarnya uuran peserta Jaminan Hari Tua (JHT) bagi peserta penerima upah yang bekerja pada pemberi kerja selain penyelenggara negara sebesar 5,7\% (lima koma tujuh persen) dari upah, dengan ketentuan:

a. $2 \%$ (dua persen) ditanggung oleh pekerja

b. 3,7\% (tiga koma tujuh persen) ditanggung oleh pemberi kerja.

Besarnya iuran program Jaminan Hari Tua (JHT) bagi Peserta penerima upah yang bekerja pada Pemberi Kerja selain penyelenggara negara dilakukan evaluasi secara berkala paling lama 3 (tiga) tahun .(Pasal 16-17 Peraturan Pemerintah Nomor 46 tahun 2015 tentang Penyelenggaraan Program Jaminan Hari Tua).

Kemudian Besarnya iuran Jaminan Hari Tua (JHT) bagi peserta bukan penerima upah didasarkan pada jumlah nominal tertentu dari penghasilan peserta yang ditetapkan dalam lampiran Peraturan Pemerintah Nomor 46 tahun 2015 tentang Penyelenggaraan Program Jaminan Hari Tua.

Besarnya iuran program JHT bagi peserta bukan penerima upah dilakukan evaluasi secara berkala paling lama 3 (tiga) tahun .(Pasal 18 Peraturan Pemerintah Nomor 46 tahun 2015 tentang Penyelenggaraan Program Jaminan Hari Tua).

\section{Jaminan Pensiun}

Usia merupakan sesuatu hal atau peristiwa $y a b=n g$ tidak mungkin bisa di hindari. Semakin tua usia pekerja maka semakin menurun produktivitasnya. Maka perusahaan ajan mengganti dengan pekerja yang usianya lebih muda dan 
perusahaan akan memutus hubungan kerja dengan pekerja yang sudah tua tersebut dengan cara memberikan pension kerja.

Untuk menghadapi resiko tersebut, maka pekerja harus mempersiapkan diri untuk menghadapi pensiunnya. Maka akan lebih baik jika pekerja itu mengikuri program Jaminan Pensiu (JP),

Yang dimaksud dengan Jaminan Pensiun adalah jaminan sosial yang bertujuan untuk mempertahankan derajat kehidupan yang layak bagi peserta dan/atau ahli warisnya dengan memberikan penghasilan setelah peserta memasuki usia pensiun, mengalami cacat total tetap, atau meninggal dunia.(Pasal 1 Peraturan Pemerintah Nomor 45 tahun 2015 tentang Penyelenggaraan Program Jaminan Pensiun).

Peserta dari program Jaminan Pensiun bisa pekerja yang bekerja pada pemberi kerja penyelenggara negara dan pekerja yang bekerja pada pemberi kerja selain penyelenggara negara.

Kepesertaan Jaminan Pensiun sebagaimana dimaksud pada ayat (1) berakhir pada saat peserta meninggal dunia dan mencapai usia pensiun dan menerima akumulasi iuran beserta hasil pengembangannya secara sekaligus.

\section{Jaminan Kematian (JKM)}

Kematian merupakan takdir yang tidak bisa di hindari oleh manusia. Termasuk pekerja tidak mungkin bisa menghindari kematian. Kematian di sini tidak hanya karena dalam pekerjaan, tetapi bisa juga Diakibatkan di luar pekerjaan, maka pekerja harus mempersiapkan diri untuk keluarganya yang ditinggalkan. Oleh sebab itu, program Jaminan Keselakaan sangat berguna untuk jaminan social bagi pekerja.']

Yang dimaksud dengan Jaminan Kematian yang selanjutnya disingkat JKM adalah manfaat uang tunai yang diberikan kepada ahli waris ketika peserta meninggal dunia bukan akibat kecelakaan kerja (Pasal 1 Peraturan Pemerintah Nomor 44 tahun 2015 tentang Penyelenggaraan Program Jaminan Kecelakaan Kerja dan Jaminan Kematian).

Peserta dari program Jaminan Kematian (JKM) bisa dilakukan oleh peserta penerima upah yang bekerja pada pemberi upah selain pemerintah atau Negara, bahkan pekerja asing yang bekerja di Indonesia minimal 6 bulan wajib menjadi peserta dan bisa di ikuti oleh bukan penerima upah.

Yudisia, Vol. 9, No.1, Jan-Jun 2018 
Peserta penerima upah, meliputi:

a. Pekerja pada perusahaan

b. Pekerja pada orang perseorangan

c. orang asing yang bekerja di Indonesia paling singkat 6 (enam) bulan.

Sedangkan peserta bukan penerima upah meliputi:

a. Pemberi kerja

b. Pekerja di luar hubungan kerja atau pekerja mandiri

c. Pekerja yang tidak termasuk huruf $\mathrm{b}$ yang bukan menerima upah.(Peraturan Pemerintah Nomor 44 tahun 2015 tentang Penyelenggaraan Program Jaminan Kecelakaan Kerja dan Jaminan Kematian).

Besarnya iuran Jaminan Kematian (JKM) bagi peserta penerima upah sebesar $0,30 \%$ (nol koma tiga puluh persen) dari pah sebulan. Iuran JKM wajib dibayar oleh Pemberi Kerja selain penyelenggara negara. Sedangkan iuran Jaminan Kematian (JKM) bagi peserta bukan penerima upah sebesar Rp 6.800,00 (enam ribu delapan ratus rupiah) setiap bulan (Peraturan Pemerintah Nomor 44 tahun 2015 tentang Penyelenggaraan Program Jaminan Kecelakaan Kerja dan Jaminan Kematian).

\section{Manfaat Jaminan Suaial bagi Tenaga Kerja}

Setelah pekerja mengikuti jamiinan social yang diselenggarakan oleh BPJS Ketenagakerjaan dengan memberiakan iuran dengan ketentuan yang berlaku, naka pekerja akan mendapat manfaat-manfaat dari jaminan soaial yang di ikutinya.

\section{Manfaat Jaminan Kecelakaan Kerja (JKK)}

Peserta yang ikut dalam program Jaminan Kecelakaan Kerja (JKK) ketika mengalami kecelakaan kerja atau penyakit akibat kerja berhak mandapatkan manfaat dari program ini. Manfaat Jaminan Kecelakaan Kerja (JKK) berupa:

a. pelayanan kesehatan sesuai kebutuhan medis yang meliputi:

1. pemeriksaan dasar dan penunjang

2. perawatan tingkat pertama dan lanjutan

3. rawat inap kelas I rumah sakit pemerintah, rumah sakit pemerintah daerah, atau rumah sakit swasta yang setara

4. perawatan intensif

5. penunjang diagnostic 
6. pengobatan

7. pelayanan khusus

8. alat kesehatan dan implant

9. jasa dokter/medisne.com

10. operasi

11. transfusi darah

12. rehabilitasi medik. (Peraturan Pemerintah Nomor 44 tahun 2015 tentang Penyelenggaraan Program Jaminan Kecelakaan Kerja dan Jaminan Kematian).

b. santunan berupa uang meliputi:

1. penggantian biaya pengangkutan peserta yang mengalami Kecelakaan Kerja atau penyakit akibat kerja, ke rumah sakit dan/atau ke rumahnya, termasuk biaya pertolongan pertama pada kecelakaan

2. santunan sementara tidak mampu bekerja

3. santunan cacat sebagian anatomis, cacat sebagian fungsi, dan cacat total tetap

4. santunan kematian dan biaya pemakaman

5. santunan berkala yang dibayarkan sekaligus apabila peserta meninggal dunia atau cacat total tetap akibat kecelakaan kerja atau penyakit akibat kerja

6. biaya rehabilitasi berupa penggantian alat bantu (orthose) dan/atau alat pengganti (prothese)

7. penggantian biaya gigi tiruan

8. beasiswa pendidikan anak bagi setiap Peserta yang meninggal dunia atau Cacat total tetap akibat kecelakaan kerja.

Beasiswa pendidikan anak diberikan sebesar $\mathrm{Rp}$ 12.000.000,00 (dua belas juta rupiah) untuk setiap peserta (Peraturan Pemerintah Nomor 44 tahun 2015 tentang Penyelenggaraan Program Jaminan Kecelakaan Kerja dan Jaminan Kematian).

Untuk besarnya manfaat uang santunan di atas dapat dilihat dalam lampiran Peraturan Pemerintah Nomor 44 tahun 2015 tentang Penyelenggaraan Program Jaminan Kecelakaan Kerja dan Jaminan Kematian

\section{Manfaat Jaminan Hari Tua (JHT)}

Peserta yang ikut dalam program Jaminan Hari Tua (JHT) ketika peserta memasuki usia pensiun, meninggal dunia, atau mengalami cacat total tetap, maka akan 
mendapatkan manfaat Jaminan Hari Tua (JHT) sebesar nilai akumulasi seluruh iuran yang telah disetor ditambah hasil pengembangannya yang tercatat dalam rekening perorangan peserta.

Pembayaran manfaat Jaminan Hari Tua (JHT) dibayar sekaligus. Kecuali dalam rangka mempersiapkan diri memasuki masa pensiun, pembayaran manfaat Jaminan Hari Tua (JHT) dapat diberikan sebagian sampai batas tertentu apabila Peserta telah memiliki masa kepesertaan paling singkat 10 (sepuluh) tahun. Dengan prosentase paling banyak 30\% (tiga puluh persen) dari jumlah Jaminan Hari Tua (JHT), yang peruntukannya untuk kepemilikan rumah atau paling banyak 10\% (sepuluh persen) untuk keperluan lain sesuai persiapan memasuki masa pensiun.

Apabila Peserta Jaminan Hari Tua (JHT) meninggal dunia, maka manfaatnya diberikan kepada ahli waris yang sah. Ahli waris yang sah meliputi:
a. janda
b. dudaumonline.com
c. anak.

Jika peserta Jaminan Hari Tua (JHT) tidak mempunyai janda, duda maupun anak, maka manfaat Jaminan Hari Tua (JHT) di berikan kepada ahli warisnya sesuai urutanm yaitu :

a. keturunan sedarah Pekerja menurut garis lurus ke atas dan

ke bawah sampai derajat kedua

b. saudara kandung

c. mertua

d. pihak yang ditunjuk dalam wasiatnya oleh Pekerja.

Di samping nendapatkan uang tunai, pesera Jaminan Hari Tua (JHT) juga akan mendapatkan manfaat layanan tambahan berupa fasilitas pembiayaan perumahan (Peraturan Pemerintah Nomor 46 tahun 2015 tentang Penyelenggaraan Program Jaminan Hari Tua).

\section{Manfaat Jaminan Pensiun (JP)}

Peserta yang ikut dalam program Jaminan Pensiun (JP) ketika peserta peserta memasuki usia pension (usia pension adalah 56 dan pada tahun 2019 menjai 57 yahun dan akan bertmbah tiga tahun sekali sampa mencapai usia 65 tahun), mengalami cacat total tetap, atau meninggal dunia., 
maka akan mendapatkan manfaat Jaminan Pensiun (JP) yang meliputi :
a. pensiun hari tua
b. pensiun cacat.hukumonline.com
c. pensiun Janda atau Duda
d. pensiun Anak
e. pensiun Orang Tua.

Penerima manfaat Jaminan Pensiun (JP) adalah :

\section{a. Peserta}

b. 1 (satu) orang istri atau suami yang sah sesuai dengan ketentuan peraturan perundang-undangan;

c. paling banyak 2 (dua) orang Anak

d. 1 (satu) orang Tua.

Manfaat pensiun hari tua didapat peserta yang sudah memiliki umr pensiun dan telah memiliki masa iur paling singkat 15 (lima belas) tahun yang setara dengan 180 (seratus delapan puluh) bulan. Jumlah manfaat pensiun hari tua dihitung dengan formula manfaat pensiun sebesar $1 \%$ (satu persen) dikali masa iur dibagi 12 (dua belas) bulan dikali rata-rata upah tahunan tertimbang selama Masa Iur dibagi 12 (dua belas).

Sedangkan manfaat pensiun cacat diterima oleh peserta yang mengalami cacat total tetap sebelum mencapai usia pensiun. Jumlah manfaat pensiun cacat dihitung dengan formula manfaat pensiun sebesar $1 \%$ (satu persen) dikali masa iur dibagi 12 (dua belas) bulan dikali rata-rata upah tahunan tertimbang selama Masa Iur dibagi 12 (dua belas). Jika masa iur kurang dari 15 (lima belas) tahun, masa iur yang digunakan dalam menghitung manfaat pensiun cacat sama seperti 15 (lima belas) tahun, dengan ketentuan:

a. Peserta rutin membayar iuran dengan tingkat kepadatan paling sedikit $80 \%$ (delapan puluh persen)

b. kejadian yang menyebabkan cacat total tetap terjadi setelah peserta terdaftar dalam program Jaminan Pensiun paling singkat 1 (satu) bulan.

Kemudian manfaat pensiun janda atau duda diterima oleh istri atau suami dari peserta yang meninggal dunia. Jumlahnya adalah :

a. 50\% (lima puluh persen) dari formula manfaat pensiun pensiun sebesar $1 \%$ (satu persen) dikali masa iur dibagi 12 
(dua belas) bulan dikali rata-rata upah tahunan tertimbang selama Masa Iur dibagi 12 (dua belas). untuk peserta yang meninggal dunia sebelum menerima manfaat pensiun

b. 50\% (lima puluh persen) dari manfaat pensiun hari tua sebesar 1\% (satu persen) dikali masa iur dibagi 12 (dua belas) bulan dikali rata-rata upah tahunan tertimbang selama Masa Iur dibagi 12 (dua belas). Jika masa iur kurang dari 15 (lima belas) tahun, masa iur yang digunakan dalam menghitung manfaat pensiun cacat sama seperti 15 (lima belas) tahun, dengan ketentuan:

a. Peserta rutin membayar iuran dengan tingkat kepadatan paling sedikit $80 \%$ (delapan puluh persen)

b. kejadian yang menyebabkan cacat total tetap terjadi setelah peserta terdaftar dalam program Jaminan Pensiun paling singkat 1 (satu) bulan.

Manfaat pensiun anak dapat diterima oleh anak ketika :

a. Peserta meninggal dunia dan tidak mempunyai istri atau suami

Jumlah pensiun anak dihitung sebesar:

1. 50\% (lima puluh persen) dari formula manfaat pensiun $1 \%$ (satu persen) dikali masa Iur dibagi 12 (dua belas) bulan dikali rata-rata Upah tahunan tertimbang selama masa iur dibagi 12 (dua belas)., untuk peserta yang meninggal dunia sebelum menerima manfaat pensiun dan tidak mempunyai janda atau duda;

2. 50\% (lima puluh persen) dari manfaat pensiun hari tua $1 \%$ (satu persen) dikali masa Iur dibagi 12 (dua belas) bulan dikali rata-rata Upah tahunan tertimbang selama masa iur dibagi 12 (dua belas)

3. $50 \%$ (lima puluh persen) dari manfaat pensiun janda atau Duda

b. Janda atau duda dari peserta meninggal dunia atau menikah lagi. Dalam hal Peserta meninggal dunia sebelum mencapai usia pensiun dan masa iur kurang dari 15 (lima belas) tahun, masa iur yang digunakan dalam menghitung manfaat pensiun anak adalah 15 (lima belas) tahun, dengan ketentuan :

a. telah menjadi peserta paling singkat 1 (satu) tahun 
b. peserta rutin membayar Iuran dengan tingkat kepadatan paling sedikit 80\% (delapan puluh persen).

Hak atas manfaat pensiun anak diperhitungkan mulai tanggal 1 bulan berikutnya setelah:

a. Peserta meninggal dunia;

b. Janda atau Duda meninggal dunia; atau

c. Janda atau Duda menikah lagi.

Manfaat pensiun orang tua diterima oleh orang tua ketikal peserta meninggal dunia dan tidak mempunyai istri, suami, atau anak. Jumlah manfaat pensiun orang dihitung sebesar:

a. $20 \%$ (dua puluh persen) dari formula manfaat pensiun sebesar 1\% (satu persen) dikali masa iur dibagi 12 (dua belas) bulan dikali rata-rata upah tahunan tertimbang selama Masa Iur dibagi 12 (dua belas)., untuk Peserta yang meninggal dunia sebelum menerima manfaat pension

b. $20 \%$ (dua puluh persen) dari manfaat pensiun hari tua atau manfaat pensiun cacat, untuk peserta yang meninggal dunia setelah menerima manfaat pensiun.

Ketika peserta meninggal dunia sebelum mencapai usia pensiun dan masa iur kurang dari 15 (lima belas) tahun, Masa Iur yang digunakan dalam menghitung manfaat pensiun orang tua adalah 15 (lima belas) tahun, dengan ketentuan:

a. telah menjadi Peserta paling singkat 1 (satu) tahun

b. Peserta rutin membayar Iuran dengan tingkat kepadatan paling sedikit $80 \%$ (delapan puluh persen). Peraturan Pemerintah Nomor 45 tahun 2015 tentang Penyelenggaraan Program Jaminan Pensiun

\section{Manfaat Jaminan Kematian (JKM)}

Manfaat Jaminan Kematian (JKM) dibayarkan kepada ahli waris, apabila peserta Jaminan Kematian meninggal dunia dalam masa aktif, Manfaat yang diperoleh meliputi :

a. santunan sekaligus Rp 16.200.000,00 (enam belas juta dua ratus ribu rupiah)

b. santunan berkala 24 x Rp200.000,00 = Rp4.800.000,00 (empat juta delapan ratus ribu rupiah) yang dibayar sekaligus

Yudisia, Vol. 9, No.1, Jan-Jun 2018 
c. biaya pemakaman sebesar Rp3.000.000,00 (tiga juta rupiah)d. beasiswa pendidikan anak diberikan kepada setiap peserta yang meninggal dunia bukan akibat kecelakaan kerja dan telah memiliki masa iur paling singkat 5 (lima) tahun. Beasiswa pendidikan diberikan sebanyak Rp 12.000.000,00 (dua belas juta rupiah) untuk setiap peserta. (Peraturan Pemerintah Nomor 44 tahun 2015 tentang Penyelenggaraan Program Jaminan Kecelakaan Kerja dan Jaminan Kematian).

\section{Kesimpulan}

Dari uraian di atas, maka dapat disimpulkan :

1. Bentuk-bentuk jaminan social bagi tenaga kerja, meliputi Jaminan Kecelakaan Kera, Jaminan Hari Tua, Jaminan Pensiun dan Jaminan Kematian.

2. Manfaat dari Jaminan Kecelakaan Kerja adalah mendapatkan pelayanan kesehatan sesuai kebutuhan medis dan santunan berupa uang. Manfaat dari Jaminan Hari Tua mendapatkan uang tunai dan pembiayaan perumahan. Sedangkan manfaat Jaminan Pensiun akan mendapatkan uang pension hari tua, pensiun cacat, pensiun janda atau duda, pensiun anak dan pensiun orang tua. Kemudian manfaat Jaminan Kematian mendapatkan santunan dan beasiswa pendidikan. 


\section{DAFTAR PUSTAKA}

Bambang Purwoko, Sistem Jaminan Sosial: Asas, Prinsip, Sifat Kepersetaan Dan Tata-Kelola penyelenggaraan Di Beberapa Negara, 2010

Imam Soepomo, Pengantar Hukum Perburuhan : Djambatan, Jakarta, 1983

Lalu Husni, Pengantar Hukum Ketenagakerjaan Indonesia, PT. Raja grafindo Persada, Jakarta, 2003

Zainal Asikin dkk, Dasar-Dasar Hukum Perburuhan, PT. Raja Grafindo Persada, Jakarta, 2002

Undang Undang Nomor 13 Tahun 2003 tentang Ketenagakerjaan Undang-Undang Nomor. 40 tahun 2004 tentang Sistem Jaminan Sosial Nasional

Undang-Undang Nomor 24 tahun 2011 tentang Badan Penyelenggara Jaminan Sosial

Peraturan Pemerintah Nomor 44 tahun 2015 tentang Penyelenggaraan Program Jaminan Kecelakaan Kerja dan Jaminan Kematian

Peraturan Pemerintah Nomor 46 tahun 2015 tentang Penyelenggaraan Program Jaminan Hari Tua

Peraturan Pemerintah Nomor 45 tahun 2015 tentang Penyelenggaraan Program Jaminan Pensiun 